\title{
Coclastogenic Effects of Sodium Arsenite on Chinese Hamster Ovary Cells (CHO9) and Primary Human Fibroblasts (VH25)
}

\author{
Radha Saraswathy \\ Department of Biosciences, Vellore Institute of Technology Deemed University, \\ Vellore 632 014, Tamil Nadu, India \\ E-mail: r_saraswathy@yahoo.com
}

\begin{abstract}
KEYWORDS Sodium arsenite; UVB; methyl methanesulfonate; mitomycin C; coclastogenicity; Chinese hamster ovary cells (CHO9); primary human fibroblasts
\end{abstract}

\begin{abstract}
The coclastogenic effects of sodium arsenite (SA) at its non-cytotoxic concentrations of $1.5 \mu \mathrm{M}$ and $3 \mu \mathrm{M}$ were studied in combination with three different types of known clastogenic agents namely ultra violet radiation (UVB, 280-320nm), methyl methanesulphonate (MMS) and mitomycin C (MMC) at varying doses/concentrations. The end points studied were the frequencies of induced sister chromatid exchanges (SCEs) and micronuclei (MN) in Chinese hamster ovary cells (CHO9) and primary human fibroblast cells (VH25). In general post treatment with SA produced synergistic increases in clastogenicity with all the three clastogens. Very few exceptions were found where increases in clastogenicity was not synergistic. In CHO9 cells post treatment with SA resulted in increased synergistic effects in the frequencies of SCEs at the lower dose/concentrations of UVB, MMS and MMC. In VH25 cells post treatment with SA produced synergistic effects in MMS and MMC induced damage in all the treatments. A similar synergistically increased frequency in MN's at the higher doses in UVB and at the lower concentrations of MMC. A non synergistic increase in MMS after post treatment with SA were observed in CHO cells. In VH25 cells, MMS in all combinations produced a synergistic effect after post treatment with SA. In general, these results demonstrate the coclastogenicity of SA with UVB, MMS and MMC treatments in $\mathrm{CHO} 9$ and VH25 cells.
\end{abstract}

\section{INTRODUCTION}

Arsenic is a known human carcinogen and an environmental pollutant (IARC monographs 1980, 1987) known to cause adverse health effects such as liver injury, neurotoxicity, increase the risk of cancers of skin, lung, bladder and liver (IARC monographs 1980; Bates et al. 1992; Chen et al. 1992; Chiou et al. 1995). Sodium arsenite (SA) can act as comutagen due to its ability to inhibit the activities of thiol containing enzymes (Sunderman 1979), such as DNA ligase (Li and Rossman, 1989b) resulting in defective DNA replication, repair, recombination and joining of single- and double-stranded DNA breaks (Lasko et al. 1990).

Earlier studies had reported that inorganic arsenicals can inhibit (a) DNA repair such as the removal of UV-induced thymidine dimers in human cells (Okui and Fujiwara 1986), (b) DNA ligase II activity in Chinese hamster V79 cells ( $\mathrm{Li}$

Corresponding author: Dr. Radha Saraswathy

Head, Department of Biosciences

Vellore Institute of Technology Deemed University

Vellore 632 014, Tamil Nadu, India

Phone: +91-416-2202640

Fax: +91-416-2243092/2240411

Email: r_saraswathy@yahoo.com and Rossman 1989b) and (c) repair of N-methyl$\mathrm{N}$-nitrosourea (MNU) - induced lesions measured by incorporation of dNMPs into damaged DNA template or by interfering with the ligation step (Li and Rossman 1989a). Jha et al. (1992) reported an interference in DNA replication-dependent processess by SA, thus leading to chromatid type of aberrations and SCEs as well as potentiating $\mathrm{X}$-rays and UV induced chromosomal damage in human peripheral lymphocytes and primary human fibroblasts.

In vitro studies (Jacobson-Kram and Montalbano 1985; Kochar et al. 1996) showed that arsenic was clastogenic and induced sister chromatid exchanges in mammalian cells. Several other studies (Jha et al. 1992; Burgdorf et al. 1977; Wen et al. 1981) also showed an enhanced sister chromatid exchanges in human lymphocytes due to arsenic exposure.

Post treatment with SA synergistically increases cytotoxicity, mutagenicity and clastogenicity of DNA crosslinking agents, Xrays, UV-light and alkylating agents in rodent and human cells (Okui and Fujiwara 1986; Jha et al. 1992; Lee et al. 1985: Lee et al. 1986a; Lee et al.1986b; Lee-Chen et al. 1993, 1994), similar to the enhancing effects of many DNA repair 
inhibitors on the DNA damage induced by known mutagens (Downes et al. 1983).

Thus, though numerous studies have indicated comutagenic, clastogenic and cytotoxic properties of SA, substantial evidence to show its coclastogenic effects at non-cytotoxic concentrations is lacking. It is well established, that UVB radiation (280-320nm), monofunctional alkylating agent methyl methanesulphonate (MMS) and polyfunctional alkylating agent mitomycin C (MMC) are clastogenic and it was proposed to investigate whether SA can potentiate the clastogenicity of these agents. Special emphasis was given to the incubation conditions and cytotoxicity, as it is important to define biological effects which occur at low, noncytotoxic concentrations of arsenite. The endpoints studied were the frequency of sister chromatid exchanges (SCEs) and frequency of chromosomal aberrations assessed as induced micronuclei (MN). MN assay was selected because its frequencies appeared to be correlated with the production of acentric fragments (Ramalho et al. 1988; Littlefield et al. 1989).

\section{MATERIALSAND METHODS}

Cell Culture: A) Chinese hamster ovary (CHO9) cells, with a cell cycle time of about $12 \mathrm{~h}$, were grown in Ham's F-10 medium supplemented with $15 \%$ fetal calf serum and antibiotics in a humidified incubator at $37^{\circ} \mathrm{C}$ and in an atmosphere of $5 \% \mathrm{CO}_{2}$ in air.

B) Primary human fibroblasts (VH25), with a cell cycle time of about 24h, were grown in Ham's F-10 medium supplemented with $15 \%$ fetal calf serum and antibiotics, in humidified incubator at $37^{\circ} \mathrm{C}$ and $2.5 \% \mathrm{CO}_{2}$ in air.

Chemicals Used: The chemicals used were MMS (Eastman Kodak, Rochester, NY), MMC (Kyowa, Japan) and SA (CAS Number 7784-465; Sigma) and were dissolved in phophatebuffered saline (PBS) just before treatment.

Experimental Design: Treatment and experimental protocols to analyse the frequency of sister chromatid exchanges (SCEs) and micronuclei $(\mathrm{MN})$ were as reported earlier from this laboratory (Natarajan et al. 1983; Dulout and Natarajan 1987).

A) Chinese hamster ovary (CHO9) cells

Treatment with SA: Cells were grown for one cell cycle $(\sim 12 \mathrm{~h})$ in a complete medium with 5-bromodeoxyuridine (BrdU, 5 $\mu \mathrm{M}$; Sigma). They were further allowed to grow with $\mathrm{SA}$ at two different concentrations $(1.5 \mu \mathrm{M}, 3 \mu \mathrm{M})$ for one cell cycle time and then were fixed. These concentrations were found to be non-cytotoxic in cell survival studies.

\section{UV Radiation}

The UVB (280-320nm) fluence rate was determined using IL700A spectro- radiometer, International light Inc. Newburyport, MA, with a cosine-corrected SEE 400 detector and a WBS 320 filter. Cells were exposed to UVB at a fluence of $4.5 \mathrm{j} / \mathrm{m}^{2} / \mathrm{sec}$ through a Mylar sheet (to eliminate wavelengths shorter than $290 \mathrm{~nm}$ ). The three doses selected were 100j, 250j and 500j.

a) UVB Treatment: The cells were washed with phospate buffered saline (PBS) and then irradiated in PBS $(10 \mathrm{ml})$. After irradiation, the cells were allowed to grow in complete medium with BrdU for $24 \mathrm{~h}$ and then were fixed.

b) $\boldsymbol{U V B}+\mathrm{SA}$ Treatment: Cells were washed with PBS, then irradiated in PBS $(10 \mathrm{ml})$ and allowed to grow in complete medium with BrdU and SA at two different concentrations $(1.5 \mathrm{mM}$, $3 \mathrm{mM}$ ) for $24 \mathrm{~h}$ and then were fixed.

\section{Treatment with Alkylating Agents}

a) Methyl methanesulfonate (MMS): Cells were grown for $12 \mathrm{~h}$ in the presence of BrdU, washed with PBS and treated for $1 \mathrm{~h}$ with MMS $(0.12,0.25$ and $0.5 \mathrm{mM})$. They were washed and allowed to grow in complete medium with BrdU for further $12 \mathrm{~h}$ and then fixed.

b) $\mathrm{MMS}+\mathrm{SA}$ : Cells were grown for $12 \mathrm{~h}$ in the presence of BrdU, washed with PBS and treated for $1 \mathrm{~h}$ with MMS $(0.12,0.25,0.5$ and $1.0 \mathrm{mM})$. They were washed with PBS and then allowed to grow in a complete medium with BrdU and SA at two different concentrations (1.5 mM, $3 \mathrm{mM}$ ) for $12 \mathrm{~h}$ and then fixed.

c) Mitomycin $C(M M C)$ and d) $M M C+S A$ : The same protocol as above was followed. The concentrations of MMC i.e. 0.03, 0.06, 0.12 and $0.24 \mathrm{mM}$ were used.

B) Primary human fibroblasts (VH25)

Treatment with SA: Confluent cells were subcultured and grown for $24 \mathrm{~h}$ in a complete medium with BrdU. They were further allowed to grow in the complete medium with BrdU, with the addition of SA (at two different concentrations $1.5 \mu \mathrm{M}, 3 \mu \mathrm{M}$ ) for $24 \mathrm{~h}$ and then fixed.

Treatment with Alkylating Agents: The experimental protocol was the same as that for CHO9 cells, except for the increased cell cycle time of $24 \mathrm{~h}$ instead of $12 \mathrm{~h}$. 
Cell Fixation and Slide Preparation: The cells were fixed in methanol: acetic acid (3: 1) and the slides were prepared by standard procedures and stained by Fluorescence plus giemsa (FPG) technique (Perry and Wolff,1974) to analyse sister chromatid exchanges (SCEs). Fifty cells from every treatment were scored and each experiment was repeated twice.

CB-MN Assay (Cytochalasin Blocked Micronucleus Assay): The experimental protocol described by Dulout and Natarajan (1987) was adopted to analyse the induced micronuclei in situ. Briefly, the cells were grown as monolayer in $24^{\prime} 24 \mathrm{~mm}$ cover glasses set in 9-cm Falcon petri dishes divided into three wells. Thus, each treatment could be replicated three times in the same petri dish. All other cell culture conditions were the same as above. After the treatment with the mutagens, the cells were washed with PBS and grown in a complete medium containing Cytochalasin B (Sigma; $3 \mu \mathrm{g} / \mathrm{ml})$ in the presence of SA for a further period of one cell cycle time. The frequency of micronuclei was estimated in the cytochalasin blocked binucleate cells. The cover glasses were fixed in 50\% methanol with two changes, air dried and stained with Acridine Orange (AO) solution $(30 \mu \mathrm{g} / \mathrm{ml})$ for 3-5 min. With AO the cytoplasm gives bright orange fluorescence and the nucleus as well as the micronuclei gives bright yellow/green when observed under a fluorescent Zeiss Axioskop microscope (Carl Zeiss) with FITC/TRITC filter. A total of 1000 binucleated cells per dose were analysed.

The concentrations used for the treatment, as well as fixation times, were determined on the basis of results obtained from our pilot experiments.

All experiments were repeated two times and the mean values with standard deviation are given in the results. The data were statistically analysed by using student's (one-tailed) t-test to estimate the level of significance. Both for SCE and $\mathrm{MN}$ analysis, the background value (control) was substracted from the total.

\section{RESULTS}

\section{CHINESE HAMSTER OVARY CELLS}

\section{i. UVB and SA Treatment}

(a) Sister Chromatid Exchanges: A dose dependent increase in the frequency of SCEs after treatment with UVB alone and in combination with SA was observed as shown in Table 1 . The frequency of SCEs (14.5 per cell) induced by the combined treatment of $100 \mathrm{j}$ UVB with $3 \mu \mathrm{M} \mathrm{SA}$ was close to the additive frequency of SCEs (14.2) induced by individual treatments of UVB (7.7) and SA (6.5). At the highest dose of UVB (500j) a synergistic effect (37.0 per cell), $21.3 \%$ more than the additive value (30.5) of UVB and SA was observed. (The term synergistic effect is used to mean that it is higher than the additive value of the effect induced independently by two different agents used in an experiment). Even though the treatment of UVB at $250 \mathrm{j}$ with $3 \mathrm{mM}$ SA produced an increase in the frequency of SCEs (25.0 per cell) over the value of any one single treatment yet it was less than the additive frequency (27.6) induced by the individual treatments. The synergistic effect of SA was found only with the highest dose of UVB employed.

Table 1: Frequency of SCEs/cell following UVB/ SA treatment in $\mathrm{CHO9}$ cells

\begin{tabular}{lrrrr}
\hline Treatment & $\begin{array}{c}\text { Observed } \\
\text { value }\end{array}$ & $\begin{array}{c}\text { S.D. } \\
( \pm)\end{array}$ & $\begin{array}{c}\text { Expected } \\
\text { additive } \\
\text { value }\end{array}$ & $\begin{array}{c}\text { Increase over } \\
\text { expected } \\
\text { value }\end{array}$ \\
\hline control & 14.7 & 3.1 & & \\
SA3uM & 6.5 & 3.9 & & \\
$100 \mathrm{j}$ & 7.7 & 4.9 & & \\
$100 \mathrm{j}+\mathrm{SA}$ & 14.5 & 7.8 & 14.2 & $+0.3(+2.1 \%)$ \\
$250 \mathrm{j}$ & 21.1 & 8.3 & & \\
$250 \mathrm{j}+\mathrm{SA}$ & 25.0 & 7.8 & 27.6 & $-2.6(-9.4 \%)$ \\
$500 \mathrm{j}$ & 24.0 & 4.7 & & \\
$500 \mathrm{j}+\mathrm{SA}$ & 37.0 & 2.0 & 30.5 & $+6.5(+21.3 \%)$ \\
\hline
\end{tabular}

(b) Micronuclei $(\boldsymbol{M N})$ : There was a dose related increase in the frequencies of $\mathrm{MN}$ after treatment with either UVB or SA. Frequency of $\mathrm{MN}$ in UVB treated cells increased by post treatment with SA (Table 2). The increased frequencies produced by the combined treatment at the lower doses, $100 \mathrm{j}$ and $250 \mathrm{j} \mathrm{UVB}$ with $1.5 \mathrm{mM}$ (82.3 and 108.6) and 3mM (95.8 and148.6) of SA were less than the additive values (130.8 and 139.6 with $1.5 \mathrm{mM} \mathrm{SA}$, and 173 and 181.8 with $3 \mathrm{mM}$ SA) of the individual treatments. However in the combined treatment at the highest dose of 500j UVB with $1.5 \mathrm{mM}$ (195.2 per cell) and $3 \mathrm{mM}(253.7$ per cell) of SA synergistic effect of 8.3 and $14.0 \%$, were observed. Thus, only at $500 \mathrm{j}$ a synergistic effect of SA was observed.

\section{ii. MMS and SA treatment}

(a) Sister Chromatid Exchanges: A dose 
Table 2: Frequency of micronuclei following UVB/SA treatment in CHO9 cells (per 1000 Binucleate cells)

\begin{tabular}{lrrcc}
\hline $\begin{array}{l}\text { Treat- } \\
\text { ment }\end{array}$ & $\begin{array}{c}\text { Observed } \\
\text { value }\end{array}$ & $\begin{array}{c}\text { S.D. } \\
( \pm)\end{array}$ & $\begin{array}{c}\text { Expected } \\
\text { additive } \\
\text { value }\end{array}$ & $\begin{array}{c}\text { Difference } \\
\text { over expected } \\
\text { value }\end{array}$ \\
\hline control & 34.4 & 11.1 & & \\
SA $1.5 \mathrm{uM}$ & 81.2 & 18.8 & & \\
$100 \mathrm{j}$ & 49.6 & 3.7 & & \\
$100 \mathrm{j}+\mathrm{SA}$ & 82.3 & 14.0 & 130.8 & $-48.5(-37.1 \%)$ \\
$250 \mathrm{j}$ & 58.4 & 9.0 & & \\
$250 \mathrm{j}+\mathrm{SA}$ & 108.6 & 15.6 & 139.6 & $-31(-22.2 \%)$ \\
$500 \mathrm{j}$ & 99.1 & 5.6 & & \\
$500 \mathrm{j}+\mathrm{SA}$ & 195.2 & 3.1 & 180.3 & $+14.9(+8.3 \%)$ \\
$\mathrm{SA3uM}$ & 123.4 & 20.1 & & \\
$100 \mathrm{j}+\mathrm{SA}$ & 95.8 & 18.0 & 173.0 & $-77.2(-44.6 \%)$ \\
$250 \mathrm{j}+\mathrm{SA}$ & 148.6 & 14.9 & 181.8 & $-33.2(-18.3 \%)$ \\
$500 \mathrm{j}+\mathrm{SA}$ & 253.7 & 2.0 & 222.5 & $+31.2(+14.0 \%)$ \\
\hline
\end{tabular}

related increase in the frequency of SCEs was observed when cells were treated either with MMS or with SA individually as shown in Table 3 . There was a moderate synergistic increase ranging from 19.8 to $26.2 \%$ in the frequency of SCEs in all the combined treatment with MMS and SA except in one combination with highest doses of both the chemicals, and this may probably be due to toxic effect resulting from that combination.

Table 3: Frequency of SCEs/cell following MMS/ SA treatment in CHO9 cells

\begin{tabular}{lrrcr}
\hline $\begin{array}{l}\text { Treat- } \\
\text { ment }\end{array}$ & $\begin{array}{c}\text { Observed } \\
\text { value }\end{array}$ & $\begin{array}{c}\text { S.D. } \\
( \pm)\end{array}$ & $\begin{array}{c}\text { Expected } \\
\text { additive } \\
\text { value }\end{array}$ & $\begin{array}{c}\text { Difference } \\
\text { over expected } \\
\text { value }\end{array}$ \\
\hline control & 16.4 & 3.9 & & \\
SA1.5uM & 0.6 & 3.1 & & \\
MMS.25 & 25.6 & 7.2 & & \\
MMS+SA & 31.5 & 6.6 & 26.2 & $+5.3(+20.2 \%)$ \\
MMS.5 & 65.0 & 9.2 & & \\
MMS+SA & 82.8 & 11.8 & $65.6+17.2(+26.2 \%)$ \\
SA3uM & 5.2 & 6.0 & & \\
MMS.25+SA 36.9 & 12.0 & 30.8 & $+6.1(+19.8 \%)$ \\
MMS.5+SA & 65.6 & 11.1 & 70.2 & $-4.6(-6.5 \%)$ \\
\hline
\end{tabular}

MMS concentration is in $\mathrm{mM}$

(b) Micronuclei $(\boldsymbol{M N})$ : A dose related increase in the frequency of $\mathrm{MN}$ was observed after treatment with MMS or SA when used singly or in combination as presented in Table 4. The increase in the MN frequencies in all the combinations showed an effect that was lower than the additive value of two single treatments.

\section{iii. MMC and SA}

(a) Sister Chromatid Exchanges: A dose dependent increase in the frequency of SCEs
Table 4: Frequency of micronuclei following MMS/SA treatment in CHO9 cells (per 1000 Binucleate cells)

\begin{tabular}{lrrrr}
$\begin{array}{l}\text { Treat- } \\
\text { ment }\end{array}$ & $\begin{array}{c}\text { Observed } \\
\text { value }\end{array}$ & $\begin{array}{c}\text { S.D. } \\
( \pm)\end{array}$ & $\begin{array}{c}\text { Expected } \\
\text { additive } \\
\text { value }\end{array}$ & $\begin{array}{c}\text { Difference } \\
\text { over expected } \\
\text { value }\end{array}$ \\
\hline control & 33.5 & 5.5 & & \\
SA1.5uM & 78.5 & 9.4 & & \\
MMS.12 & 97.3 & 44.7 & & \\
MMS+SA & 132.9 & 7.8 & 175.8 & $-42.9(-24.4 \%)$ \\
MMS.25 & 110.6 & 13.7 & & \\
MMS+SA & 156.5 & 15.3 & 189.1 & $-32.6(-17.2 \%)$ \\
MMS.5 & 247.5 & 11.3 & & \\
MMS+SA & 272.5 & 17.6 & 326.0 & $-53.5(-16.4 \%)$ \\
SA3uM & 134.4 & 10.1 & & \\
MMS.12+SA & 112.3 & 7.3 & 231.7 & $-119.4(-51.5 \%)$ \\
MMS.25+SA & 227.2 & 54.7 & 245.0 & $-17.8(-7.3 \%)$ \\
MMS.5+SA & 248.0 & 2.4 & 381.9 & $-133.9(-35.1 \%)$ \\
\hline
\end{tabular}

MMS concentration is in $\mathrm{mM}$

after treatment with MMC or SA singly and in combination was observed, as shown in Table 5.

A synergistic effect at the $0.12 \mathrm{mM}$ and $0.24 \mathrm{mM} \mathrm{MMC}$ and a less than additive value at $0.03 \mathrm{mM} \mathrm{MMC}+\mathrm{SA}(1.5 \mathrm{mM}$ and $3 \mathrm{mM})$ and in $0.24 \mathrm{mM}$ MMC+SA $3 \mathrm{mM}$ were observed.

Table 5: Frequency of SCEs/cell following MMC/ SA treatment in $\mathrm{CHO9}$ cells

\begin{tabular}{lrrrr}
\hline $\begin{array}{l}\text { Treat- } \\
\text { ment }\end{array}$ & $\begin{array}{c}\text { Observed } \\
\text { value }\end{array}$ & $\begin{array}{c}\text { S.D. } \\
( \pm)\end{array}$ & $\begin{array}{c}\text { Expected } \\
\text { additive } \\
\text { value }\end{array}$ & $\begin{array}{c}\text { Difference } \\
\text { over expected } \\
\text { value }\end{array}$ \\
\hline control & 16.4 & 3.9 & & \\
SA1.5uM & 0.6 & 3.1 & & \\
MMC.03 & 3.8 & 4.8 & & $-0.2(-4.5 \%)$ \\
MMC+SA & 4.2 & 4.5 & 4.4 & \\
MMC.12 & 4.3 & 4.6 & & \\
MMC+SA & 9.2 & 4.5 & 4.9 & $+4.3(+87.7 \%)$ \\
MMC.24 & 14.1 & 6.9 & & \\
MMC+SA & 16.7 & 7.5 & 14.7 & $+2.0(+13.6 \%)$ \\
SA3uM & 5.2 & 6.0 & & $-2.9(-32.2 \%)$ \\
MMC.03+SA & 6.1 & 7.0 & 9.0 & $-2.5(+15.8 \%)$ \\
MMC.12+SA & 11.0 & 7.3 & 9.5 & $+1.5(-2 \%)$ \\
MMC.24+SA & 15.4 & 7.4 & 19.3 & $-3.9(-20.2 \%)$ \\
\hline MMC concentration is in $\mathrm{mM}$ &
\end{tabular}

(b) Micronuclei $(\boldsymbol{M N})$ : A dose dependent increase in the frequencies of $\mathrm{MN}$ was obtained after treatment with MMC or SA used singly or in combination as shown in Table 6. A synergistic increase ranging from 13.0 to $105.7 \%$ in the frequencies of MN was observed in all the combinations with all doses of MMC and SA over the expected additive values. However the highest doses of $\mathrm{MMC}+\mathrm{SA}(0.24 \mathrm{mM}+3 \mathrm{mM})$ resulted in a lower frequency of induction of $\mathrm{MN}$ which may be due to toxic effect of the combination treatment (expected value/observed value, 224.3/114.1). 
Table 6: Frequency of micronuclei following MMC/SA treatment in CHO9 cells (per 1000 Binucleate cells)

\begin{tabular}{lrrrc}
\hline $\begin{array}{l}\text { Treat- } \\
\text { ment }\end{array}$ & $\begin{array}{c}\text { Observed } \\
\text { value }\end{array}$ & $\begin{array}{c}\text { S.D. } \\
( \pm)\end{array}$ & $\begin{array}{c}\text { Expected } \\
\text { additive } \\
\text { value }\end{array}$ & $\begin{array}{c}\text { Difference } \\
\text { over expected } \\
\text { value }\end{array}$ \\
\hline control & 33.5 & 5.5 & & \\
SA1.5uM & 78.5 & 9.4 & & \\
MMC.03 & 34.5 & 44.7 & & \\
MMC+SA & 232.5 & 7.8 & $113.0+119.5(+105.7 \%)$ \\
MMC.12 & 67.3 & 13.7 & & \\
MMC+SA & 241.7 & 15.3 & $145.8+95.9(+65.8 \%)$ \\
MMC.24 & 89.9 & 11.3 & & \\
MMC+SA & 235.6 & 17.6 & 168.4 & $+67.2(+39.9 \%)$ \\
SA3uM & 134.4 & 10.1 & & \\
MMC.03+SA 216.3 & 7.3 & $168.9+47.4(+28.1 \%)$ \\
MMC.12+SA 228.0 & 54.7 & 201.7 & $+26.3(+13.0 \%)$ \\
MMC.24+SA 114.1 & 2.4 & $224.3-110.2(-49.1 \%)$ \\
\hline MMC concentration is in $\mathrm{mM}$
\end{tabular}

\section{PRIMARY HUMANFIBROBLASTS}

\section{i. MMS and SA treatment}

(a) Sister Chromatid Exchanges: A doserelated increase in the frequency of SCE was observed when cells were treated either with MMS or with SA individually and in combination. As shown in Table 7, a synergistic increase ranging from 5.9 to $88.5 \%$ over the expected additive values in the frequency of SCE in all the combined treatments was observed.

Table 7: Frequency of SCEs/cell following MMS/ SA treatment in $\mathbf{V H 2 5}$ cells

\begin{tabular}{|c|c|c|c|c|}
\hline $\begin{array}{l}\text { Treat- } \\
\text { ment }\end{array}$ & $\begin{array}{l}\text { bserved } \\
\text { value }\end{array}$ & $\begin{array}{l}\text { S.D. } \\
( \pm)\end{array}$ & $\begin{array}{c}\text { Expected } \\
\text { additive } \\
\text { value }\end{array}$ & $\begin{array}{c}\text { Increase } \\
\text { over expected } \\
\text { value }\end{array}$ \\
\hline control & 10.5 & 3.4 & & \\
\hline $\mathrm{SA} 1.5 \mu \mathrm{M}$ & 5.3 & 5.0 & & \\
\hline MMS.25 & 6.9 & 4.6 & & \\
\hline $\mathrm{MMS}+\mathrm{SA}$ & 16.5 & 7.1 & 12.2 & $+4.3(+35.2 \%)$ \\
\hline MMS.5 & 29.4 & 10.9 & & \\
\hline $\mathrm{MMS}+\mathrm{SA}$ & 58.1 & 27.1 & 34.7 & $+23.4(67.4 \%)$ \\
\hline $\mathrm{SA} 3 \mu \mathrm{M}$ & 6.1 & 4.6 & & \\
\hline MMS.25+SA & 24.5 & 4.4 & 13.0 & $+11.5(+88.5 \%)$ \\
\hline MMS.5+SA & 37.6 & 10.1 & 35.5 & $+2.1(+5.9 \%)$ \\
\hline
\end{tabular}

(b) Micronuclei $(M N)$ : A dose dependent increase in the frequency of $\mathrm{MN}$ was obtained after treatment with MMS, only at the low concentrations $(0.25$ and $0.5 \mathrm{mM})$. At the highest dose of MMS $(1.0 \mathrm{mM})$, the increase in the frequency of MN was not dose related most probably due to toxic effect of the combined treatment. As presented in Table 8, the frequency of MN in MMS treated cells was increased by post treatment with SA. However, the frequencies of MN (38.1 and 36.2) in the combined treatments $(0.25 \mathrm{mM}$ MMS with $1.5 \mathrm{mM}$ SA and $3 \mathrm{mM} \mathrm{SA}$ respectively) were less than the respective additive values (71.0 and 78.2). At the combination of higher concentrations $(0.5$ and $1.0 \mathrm{mM})$ with SA $(1.5$ and $3 \mu \mathrm{M})$ a synergistic increase ranging from 2.9 to $48.8 \%$ over the additive value was noticed.

Table 8: Frequency of micronuclei following MMS/ SA treatment in VH25 cells (per 1000 Binucleate cells)

\begin{tabular}{|c|c|c|c|c|}
\hline $\begin{array}{l}\text { Treat- } \\
\text { ment }\end{array}$ & $\begin{array}{c}\text { Observed } \\
\text { value }\end{array}$ & $\begin{array}{l}S . D . \\
( \pm)\end{array}$ & $\begin{array}{c}\text { Expected } \\
\text { additive } \\
\text { value }\end{array}$ & $\begin{array}{c}\text { Difference } \\
\text { over expected } \\
\text { value }\end{array}$ \\
\hline control & 20.0 & 3.7 & & \\
\hline $\mathrm{SA} 1.5 \mu \mathrm{M}$ & 39.5 & 9.1 & & \\
\hline MMS. 25 & 31.5 & 9.8 & & \\
\hline $\mathrm{MMS}+\mathrm{SA}$ & 38.1 & 7.3 & 71.0 & $-32.9(-46.3 \%)$ \\
\hline MMS.5 & 165.5 & 49.5 & & \\
\hline $\mathrm{MMS}+\mathrm{SA}$ & 305.0 & 6.0 & $205.0+$ & $-100.0(+48.8 \%)$ \\
\hline MMS 1.0 & 85.5 & 5.4 & & \\
\hline $\mathrm{MMS}+\mathrm{SA}$ & 143.2 & 2.7 & 125.0 & $+18.2(+14.6 \%)$ \\
\hline $\mathrm{SA} 3 \mu \mathrm{M}$ & 46.7 & 8.3 & & \\
\hline MMS.25+SA & A 36.2 & 9.1 & 78.2 & $-42.0(-53.7 \%)$ \\
\hline MMS.5+SA & 283.3 & 6.2 & 212.2 & $+71.1(+33.5 \%)$ \\
\hline MMS1.0+SA & A 136.0 & 3.2 & 132.2 & $+3.8(+2.9 \%)$ \\
\hline
\end{tabular}

MMS concentration is in $\mathrm{mM}$

\section{ii. MMC and SA}

(a) Sister Chromatid Exchanges: A dose dependent increase in the frequency of SCE was obtained in treatment with MMC and SA. A moderate synergistic effect more than the additive value of single treatments with MMC and SA was observed in all the combined treatments of MMC and SA (Table 9) except in the combinations of $0.06 \mathrm{mM} \mathrm{MMC}$ with 1.5 and $3 \mathrm{mM}$ SA.

Table 9: Frequency of SCEs/cell following MMC/ SA treatment in $\mathrm{VH25}$ cells

\begin{tabular}{lrrcc}
\hline $\begin{array}{l}\text { Treat } \\
\text { ment }\end{array}$ & $\begin{array}{c}\text { Observed } \\
\text { value }\end{array}$ & $\begin{array}{c}\text { S.D. } \\
( \pm)\end{array}$ & $\begin{array}{c}\text { Expected } \\
\text { additive } \\
\text { value }\end{array}$ & $\begin{array}{c}\text { Difference } \\
\text { over expected } \\
\text { value }\end{array}$ \\
\hline control & 10.5 & 3.4 & & \\
SA1.5uM & 5.3 & 5.0 & & \\
MMC.03 & 30.1 & 14.7 & & \\
MMC+SA & 37.5 & 9.6 & 35.4 & $+2.1(+5.9 \%)$ \\
MMC.06 & 32.2 & 11.6 & & \\
MMC+SA & 37.4 & 10.8 & 37.5 & $-0.1(-0.3 \%)$ \\
SA 3 $\mu M$ & 6.1 & 4.6 & & \\
MMC.03+SA & 39.5 & 3.4 & 36.2 & $+3.3(+9.1 \%)$ \\
MMC.06+SA & 36.6 & 4.5 & 38.3 & $-1.7(-4.4 \%)$ \\
\hline
\end{tabular}

MMC concentration is in $\mathrm{mM}$ 
(b) Micronuclei $(\boldsymbol{M N})$ : A dose dependent increase in frequency of MN was also observed in single treatments either with MMC, SA or in combination. A synergistic effect ranging from 74.6 to $176.0 \%$ over the additive frequencies was observed in all the combined treatments except in the treatment at the highest dose level of $0.06 \mathrm{mM} M M C+3 \mu \mathrm{M} \mathrm{SA}$ (Table10).

Table 10 : Frequency of micronuclei following MMC/SA treatment in VH25 cells (per 1000 Binucleate cells)

\begin{tabular}{lrrrr}
\hline $\begin{array}{l}\text { Treat- } \\
\text { ment }\end{array}$ & $\begin{array}{c}\text { Observed } \\
\text { value }\end{array}$ & $\begin{array}{c}\text { S.D. } \\
( \pm)\end{array}$ & $\begin{array}{c}\text { Expected } \\
\text { additive } \\
\text { value }\end{array}$ & $\begin{array}{c}\text { Difference } \\
\text { over expected } \\
\text { value }\end{array}$ \\
\hline control & 20.0 & 3.9 & & \\
SA1.5uM & 39.5 & 9.1 & & \\
MMC.03 & 7.7 & 2.1 & & \\
MMC+SA & 100.4 & 6.5 & 47.2 & $+53.2(+112.7 \%)$ \\
MMC.06 & 24.7 & 6.0 & & \\
MMC+SA & 177.2 & 4.2 & $64.2+113.0(+176.0 \%)$ \\
MMC.12 & 61.1 & 2.7 & & \\
MMC+SA & 175.7 & 4.0 & 100.6 & $+75.1(+74.6 \%)$ \\
SA3uM & 46.7 & 8.3 & & \\
MMC.03+SA 146.4 & 8.5 & 54.4 & $+92.0(+169.1 \%)$ \\
MMC.06+SA & 26.3 & 5.8 & 71.4 & $-45.1(-63.2 \%)$ \\
\hline
\end{tabular}

MMC concentration is in $\mathrm{mM}$

\section{DISCUSSION}

In $\mathrm{CHO} 9$ cells, $\mathrm{SA}$ and all the three clastogenic agents studied i.e. UVB, MMS and MMC with different modes of action were found to be effective in producing SCEs and MN. It is known that mutagens such as UVB and alkylating agents (MMS and MMC) require S-dependent repair of induced DNA lesions for the formation of chromosomal aberrations as well as SCEs (Perry and Evans 1975; Kihlman 1977; Natarajan and Obe 1982).

In VH25 cell line also, an effective induction of SCEs and MN with MMS, MMC and SA was observed. However the frequency of SCEs produced by MMS in VH25 cells was lower than that was observed in $\mathrm{CHO}$ cells. Similar frequencies of SCEs in both the cell lines were produced by MMC and SA.

Coclastogenic Effect of SA with UVB in CHO9 Cells: Arsenic has been shown to enhance the cytotoxicity, mutagenicity and clastogenicity in combination with UV radiation, $\mathrm{X}$-rays, alkylating agents as well as DNA crosslinking compounds in cultured mammalian cells (Hartwig, 1995; Hartmann and Speit, 1996). The cocytotoxic effect of arsenite in excision of pyrimidine dimers has been reported (Okui and Fujiwara 1986) in normal human fibroblasts.
There was a synergistic increase in the frequency of SCEs produced by UVB after treatment with SA at all doses except 250j of UVB. The UVB clastogenicity and the enhancing effect of SA on it may be due to the interference of SA in excision repair.

Earlier studies (Jha et al. 1992; Lee et al. 1985) showed that post treatment with sodium arsenite synergistically increased the UVC induced chromosomal aberrations. Huang et al. (1992) studied the enhancing effect of arsenite on chromosomal aberrations induced by UVC at various points in the cell cycle and reported a coclastogenic effect of SA by treating cells at late G1/S transition with UVC and arsenic. They also suggested that the inhibition of dimer excision might be important than the inhibition of ligation for the expression of coclastogenic effect, as chromatid exchanges were believed to result from misjoining of two double-strand breaks, as observed in the combined treatment of UVC and SA treated in late $\mathrm{G} 1$ of CHO cells. This is supported by the results of our study where a synergistic increase in the frequency of SCEs was observed, when UVB treated cells were post treated with SA.

The dose dependent increase in the MN frequency of UVB + SA treated cells probably resulted from the inhibition of DNA ligation by SA as has been earlier reported (Jha et al. 1992; Lee et al. 1985, 1986a, b) using UVC + SA. In CHO9 cells synergistic effect of SA with UVB and $\mathrm{MMC}$ in the induced frequency of MN was noticed at higher doses/concentrations of UVB and MMC and no synergistic effect with MMS was noticed.

Coclastogenic Effect of SA with MMS and MMC in CHO9 and VH25 Cells:_As in the case of UVB, SA potentiated the effects of MMS and MMC in the induction of SCEs. Post treatment with SA and MMS and MMC treated cells produced synergistic effect at lower concentrations and at the highest concentration the effect was reduced, which may be due to the cytotoxic effect of the combination of MMS or MMC with SA. This is also supported by the report (Hartwig, 1995) that in AS III and other metal ions DNA repair processes were disturbed at low non-cytotoxic concentrations.

However, in VH25 cells a synergistic effect in the production of $\mathrm{MN}$ at all doses except in one with MMC and two with MMS after SA was observed. This shows a differential sensitivity 
of two cell lines namely $\mathrm{CHO} 9$ and $\mathrm{VH} 25$, in the production of chromosomal aberrations (MN) when treated with MMS. This difference in response may be related to the known different kinetics of nucleotide or base excision repair capacity of these two cell lines.

Although frequencies of SCEs in both cell lines in MMS treated cells were synergistically increased after post treatment with SA the increase in the frequency of $\mathrm{MN}$ was lower than the additive value of two single treatments. This observation shows that there may be different pathways leading to the formation of SCEs and chromosomal aberrations (MN) depending on the type of lesions responsible for these endpoints.

SA post treatment synergistically increased the frequency of SCEs and MN induced by MMC in CHO cells. These results are similar to those reported in the combined treatment of cross-linking agents, Cis-diammine dichloroplatinum (II) (Cis-ptII) and 8-methoxypsoralen (8MOP) with SA (Lee et al. 1986b) in CHO cells.

As alkylating agents are S-dependent clastogen and induce chromatid type of aberrations and when SA is also present during $\mathrm{S}$ phase of the cell cycle, an increase in clastogenicity can be observed. Earlier studies (Jha et al. 1992) had also shown that SA could act as a clastogen when present during S-phase of the cell cycle by interfering with DNA replication process.

Present results suggest that non-cytotoxic concentrations of SA enhances the clastogenicity of UVB, MMS and MMC in CHO9 cells and primary human fibroblasts (VH25). Its coclastogenic effect is S-dependent and not restricted to certain types of DNA lesions alone. This study adds further evidence that SA inhibits DNA repair process and interferes with DNA replication-dependent processes in UVB, MMS and MMC treated cells leading to induction of sister chromatid exchange and micronuclei.

\section{ACKNOWLEDGEMENTS}

This work was carried out with the help of Prof. A.T. Natarajan, The Netherlands and Prof. K. M. Marimuthu, Prof. Emeritus, Department of Genetics, Madras University, Chennai, Tamil Nadu, India.

\section{REFERENCES}

Bates MN, Smith AH, Hopenhayn-Rich C 1992. Arsenic ingestion and internal cancers: A review. Am J Epidemiol,135: 462-476.

Burgdorf W, Kurvink K, Cervenka J 1977. Elevated sister chromatid exchange rate in lymphocytes of subjects treated with arsenic. Hum Genet, 36: 6972 .

Chen CJ, Chen CW, Wu MM, Kuo TT 1992. Cancer potential in liver, lung, bladder and kidney due to ingested inorganic arsenic in drinking water. $\mathrm{Br} \mathrm{J}$ Cancer, 66: 888-892.

Chiou HY, Hsueh Y-M , Liaw K-F, Horng S-F, Chiang MH, Pu Y-S, Lin JS-N, Huang C-H, Chen C-J 1995. Incidence of internal cancers and ingested inorganic arsenic: A seven-year follow-up study in Taiwan. Cancer Res, 55: 1296-1300.

Downes CS, Collins ARS, Johnson RJ 1983. International workshop on inhibition of DNA repair. Mutat Res, 112: $75-83$.

Dulout FN, Natarajan AT 1987. A simple and reliable in vitro test system for the analysis of induced aneuploidy as well as other cytogenetic endpoints using Chinese hamster cells. Mutagenesis, 2: 121126.

Hartwig A 1995. Current aspects in metal genotoxicity. Biometals, 8: 3-11.

Hartmann A, Speit G 1996. Effect of arsenic and cadmium on the persistence of mutagen-induced DNA lesions in human cells. Environ Mol Mutagen, 27: 98-104.

Huang H, Huang CF, Huang JS, Wang TC, Jan KY 1992. The transition from late $\mathrm{G} 1$ to early $\mathrm{S}$ phase is most vulnerable to the co-clastogenic effect of ultraviolet radiation plus arsenite. Int J Radiat Biol, 61: $57-62$.

IARC Monographs 1980. On the Evaluation of Carcinogenic Risks to Humans-Some Metals and Metallic Compounds. Lyon pp.23.

IARC Monographs 1987. On the evaluation of carcinogenic risks to humans-Overall evaluation of carcinogenicity: An updating of IARC monographs. Suppl. 7 Lyon pp.1-42.

Jacobson-Kram D, Montalbano D 1985. The reproductive effects assessment group's report of mutagenicity of inorganic arsenic. Environ Mutagen, 7: 707-804

Jha AN, Noditi M, Nilsson R, Natarajan AT 1992. Genotoxic effects of sodium arsenite on human cells. Mutat Res, 284: 215-221.

Kihlman BA 1977. Caffeine and Chromosomes. Amsterdam: Elsevier

Kochar TS, Howard W, Hoffman S, Brammer-Carleton L 1996. Effect of trivalent and pentavalent arsenic in causing chromosome alterations in cultured Chinese hamster ovary (CHO) cells. Toxicol Lett, 84: $37-42$.

Lasko DD, Tomkinson AE, Lindahl T 1990. Eukaryotic DNA ligases. Mutat Res, 236 (2-3): 277-287.

Lee TC, Huang RY, Jan KY 1985. Sodium arsenite enhances the cytotoxicity, clastogenicity, and 6thioguanine-resistant mutagenicity of ultraviolet light in Chinese hamster ovary cells. Mutat Res, 148: $83-86$.

Lee TC, Tzeng SF, Chang WJ, Lin YC, Jan KY 1986a. Differential effects of pre and post treatment of sodium arsenite on the genotoxicity of methyl 
methanesulfonate in Chinese hamster ovary cells. Cancer Res, 46: 1854-1857.

Lee TC, Lee KC, Tzeng YJ, Huang RY, Jan KY 1986b. Sodium arsenite potentiates the clastogenicity and mutagenicity of DNA cross-linking agents. Environ Mutagen, 8: 119-128.

Lee-Chen SF, Gurr JR, Lin IB, Jan KY 1993. Arsenite enhances DNA double strand breaks and cell killing of methyl methanesulfonate treated cells by inhibiting the excision of alkali labile sites. Mutat Res, 294: 21-28.

Lee-Chen SF, Yu CT, Wu DR, Jan KY 1994. Differential effects of luminol, nickel and arsenite on the rejoining of ultraviolet light and alkylation-induced DNA breaks. Environ Mol Mutagen, 23: 116-120.

Li J-H, Rossman TG 1989a. Mechanism of comutagenesis of sodium arsenite with N-methyl-Nnitrosourea. Biol Trace Element Res, 21: 373-381.

Li J-H, Rossman TG 1989b. Inhibition of DNA ligase activity by arsenite: a possible mechanism of its comutagenesis. Mol Toxicol, 2: 1-9.

Littlefield LG, Sayer AM, Frome EL 1989. Comparisons of dose-response parameters for radiation-induced acentric fragments and micronuclei observed in cytokinesis-arrested lymphocytes. Mutagenesis, 4: 265-270.

Natarajan AT, Obe G 1982. Mutagenicity testing with cultured mammalian cells, Cytogenetic assays. In: JA Heddle (Ed.): Mutagenicity- New horizons Genetic Toxicology. New York: Academic Press, pp. 172-213.
Natarajan AT, Tates AD, Meijers M, Neuteboom I, deVogel N 1983. Induction of sister-chromatid exchanges (SCEs) and chromosomal aberrations by mitomycin $\mathrm{C}$ and methyl methanesulfonate in Chinese hamster ovary cells. An evaluation of methodology for detection of SCEs and of persistant DNA lesions towards the frequencies of observed SCEs. Mutat Res, 121: 211-223.

Okui T, Fujiwara Y 1986. Inhibition of human excision DNA repair by inorganic arsenic and the comutagenic effect in V79 Chinese hamster cells. Mutat Res, 172: 69-76.

Perry P, Wolff S 1974. New Giemsa method for the differential staining of sister chromatids. Nature, 251: 156-157.

Perry P, Evans HJ 1975. Cytological detection of mutagen-carcinogen exposure by sister chromatid exchange. Nature, 258: 121-125.

Ramalho AT, Sunjevaric I, Natarajan AT 1988. Use of the frequencies of micronuclei as quantitative indicators of X-ray induced chromosomal aberrations in human peripheral blood lymphocytes: comparison of two methods. Mutat Res, 207 (3-4): 141-146.

Sunderman FW 1979. Mechanisms of metal carcinogens. Biol Trace Elements Res, 1: 63-86.

Wen WN, Lieu TL, Chang HJ, Wuu SW, Yau ML, Jan KY 1981. Baseline and sodium arsenite induced sister chromatid exchanges in cultured lymphocytes from patients with Blackfoot disease and healthy persons. Hum Genet, 59: 201-203. 